\title{
Entrepreneurial Universities: Emerging Models in the New Social and Economic Landscape
}

\author{
Maribel Guerrero, David Urbano, Fayolle Alain, Magnus Klofsten and Sarfraz Mian
}

\author{
Linköping University Post Print
}

\section{Tweet}

N.B.: When citing this work, cite the original article.

The original publication is available at www.springerlink.com:

Maribel Guerrero, David Urbano, Fayolle Alain, Magnus Klofsten and Sarfraz Mian, Entrepreneurial Universities: Emerging Models in the New Social and Economic Landscape, 2016, Small Business Economics, (), , 1-13.

http://dx.doi.org/10.1007/s11187-016-9755-4

Copyright: Springer Verlag (Germany)

http://www.springerlink.com/?MUD=MP

Postprint available at: Linköping University Electronic Press

http://urn.kb.se/resolve?urn=urn:nbn:se:liu:diva-129394 


\title{
Entrepreneurial universities: emerging models in the new social and economic landscape
}

\author{
Maribel Guerrero • David Urbano • \\ Alain Fayolle $\cdot$ Magnus Klofsten $\cdot$ Sarfraz Mian
}

Accepted: 7 June 2016

(C) Springer Science+Business Media New York 2016

\begin{abstract}
The purpose of this paper and the special issue is to improve our understanding of the theoretical, empirical, managerial and political implications of emerging models of entrepreneurial universities in the new social and economic landscape. We accomplish this objective by examining the role of entrepreneurial universities as drivers of innovation and entrepreneurship activities. Our analysis starts with an overview by outlining an overarching framework. This allows us to highlight the contributions made in this special issue within the framework. We conclude by outlining an agenda for future research and discuss implications for university managers, policy makers, and other
\end{abstract}

M. Guerrero $(\square)$

Department of Strategy, Deusto Business School,

University of Deusto, Po Mundaiz, 50,

20012 Donostia-San Sebastián, Spain

e-mail: maribel.guerrero@deusto.es

D. Urbano

Department of Business, Universitat Autònoma de

Barcelona, Building B, 08193 Barcelona, Spain

A. Fayolle

EM Lyon Business School, 23 Avenue Guy de Collongue, 69130 Écully, Francia

M. Klofsten

Linköping University/CIE, 58183 Linköping, Sweden

S. Mian

School of Business, State University of New York, Oswego, NY, USA academic agents involved in the development of entrepreneurial/innovation ecosystems.

Keywords Entrepreneurial university - Innovation · Entrepreneurship $\cdot$ Ecosystem $\cdot$ Social and economic landscape $\cdot$ Impacts $\cdot$ USA $\cdot$ Europe

\section{Introduction}

During the past few decades, the configurations of new knowledge-intensive environments have required fertile settings for innovative and entrepreneurial activities. Both types of activities play a crucial role in the economy, and many studies have examined the factors that influence these activities (Autio et al. 2014). Those facts explain why both activities have been operationalized in different ways (e.g., with/without government intervention, closed/opened, administrated/entrepreneurially) in different spaces (e.g., global, national, regional, local) and in different contexts (e.g., organizational, institutional, technological, social). Because of this diversity, there has been growing interest in the study of how organizations transform their roles and practices in the development and strengthening of national innovation and entrepreneurial ecosystems (Etzkowitz and Leydesdorff 2000).

Despite innovation and entrepreneurship being multidimensional processes, empirical studies continue to employ models that presume that these 
phenomena occur at a single point in time (McMullen and Dimov 2013). More concretely, the innovation literature was mostly about structures and institutions, while the entrepreneurship literature has been mostly about individuals or firms (Zahra and Wright 2011). According to Autio et al. (2014), in both temporal and spatial contexts, entrepreneurial innovation is the result of a variety of elements that compare the attributes of national innovation systems, entrepreneurship, contextual influences and the main benefits for the actors involved in this process. Interestingly, if we analyze the literature of innovation ecosystems (Carlsson et al. 2002; Castellacci and Natera 2013; Zahra and Wright 2011) and entrepreneurship ecosystems (Isenberg 2010; Mason and Brown 2014), in both bodies of literature the role of universities is crucial in the development of human capital, knowledge capital, and entrepreneurship capital.

Applying this perspective, how universities operate, collaborate, make decisions, identify benefits, or transform their roles is still an interesting research area (Cunningham and Link 2015). Indeed, in the hope of facilitating economic growth, many nations, regions, and states have adopted policies to stimulate innovation by entrepreneurial firms. In general, those policies include local, regional, and national initiatives to promote and to facilitate technology-based entrepreneurship (Mustar and Wright 2010; Grimaldi et al. 2011). In this sense, the governments mobilize universities as a part of the strategy to stimulate regional economic development (Cohen et al. 2002). As a result, the emerging role of a modern entrepreneurial university is dichotomous, focusing both innovation and entrepreneurship that contributes to innovation, competiveness, and economic growth (Audretsch 2014; Urbano and Guerrero 2013).

A number of universities are currently in a state of transition because they are expected to develop a wide range of relationships with stakeholders in order to enhance this dichotomous contribution. Therefore, universities are changing (in content, structure, governance, and strategies) and evolving not as a process of co-creation but rather in a series of transitions whereby multiple stakeholders are continually shaping/adapting the university model (Miller et al. 2014). This development of universities has sometimes been described as an 'Evolution of ivory tower to entrepreneurial paradigm' (Etzkowitz et al. 2000, p. 325). Particularly, it takes more relevance in the worldwide economic downturn that began in 2008 represented a strategic game changer for most organizations. Severe resource constraints and unpredictable conditions created significant challenges for organizational survival, let alone growth through innovation and venturing activities. ${ }^{1}$ Therefore, in this scenario, the entrepreneurial universities also face strong challenges, higher rates of unemployment, the reduction of education budgets, and reduction in the demand of higher education studies.

Based on this new social and economic landscape, this special issue was inspired on the role of Entrepreneurial Universities at the regional/national level and exploring the way they interacts with other stakeholders in their regions and on the impacts produced by those interactions on the regional innovative/entrepreneurial capacity toward sustained socio-economic well-being. More concretely, the purpose is to improve the understanding of the theoretical, empirical, managerial, and political implications of emerging models of entrepreneurial universities in the new social and economic landscape. To achieve this objective, this paper presents seven papers $^{2}$ that combined diverse theoretical (networks, agency theory, institutional theory, internationalization ...) and methodological (multilevel, OLS ...) approaches employed in the USA and European contexts. ${ }^{3}$

The remainder of this paper is organized as follows. Section 2 elaborates a framework for our articulation of the role of entrepreneurial universities as drivers of innovation and entrepreneurship. Section 3 provides summaries of the papers included in this issue and the lessons learned. In Sect. 4, we outline an agenda for additional research on this topic and the policy implications. In Sect. 5, we conclude by outlining our general conclusions.

\footnotetext{
${ }_{1}$ Specially, USA and Europe experimented the strong effects of this economic transition (Van Der Zwan et al. 2013; Charles et al. 2014).

2 During the period of December 2014 to April 2016, these papers were selected from 45 proposal received from researchers located across the world. The final selection was based on double reviews.

${ }^{3}$ In order to boost innovation and to promote entrepreneurship, public policy has also actively supported the 'mission-oriented' countries like the UK and USA (Brown and Mason 2014).
} 


\section{Entrepreneurial universities as drivers of innovation and entrepreneurship: an overview}

Given the relevance of this topic, during the last two decades, the role of universities in promoting entrepreneurship and innovation has been the focus of attention of policy makers and academics from different disciplines (i.e., economics, psychology, and sociology) and perspectives (i.e., individual, organizational, and contextual). Interesting examples have been published in regular and special issues of well recognized journals (see Table 1).

Based on these special issue publications, the academia has contributed to this topic: (1) at organizational level, with interesting papers published regarding the creation of spin-offs, technology transfers, science parks, incubators, and relationships among several external organizations (industry); and (2) at individual level with several papers that have explored the relevance of entrepreneurial education, opportunity recognitions, and intention. Based on these theoretical/empirical studies, we pay attention to the role of entrepreneurial universities as drivers of innovation and entrepreneurship activities, particularly, on the interactions among individuals/organizations, as well as, organizations/contexts in the definition of entrepreneurial university models. These interactions are key elements in the emergence of opportunities (Busenitz et al. 2014).

\subsection{Research university as a source of knowledge (technology) providing innovative contexts}

For neoclassical economist's knowledge has been an independent variable in the sense that it is considered external to the economic system; that is, in the production function technical change is taken as the residual that could not be explained directly by the key input factors, capital, and labor. Nevertheless, by the beginning of the $1980 \mathrm{~s}$, most economists started to interpret technology as an endogenous variable to be explained by the economic conditions of production, which for neoclassical thought is already becoming the systematized theory of 'endogenous economic growth' (Corona et al. 2006). Therefore, the endogenous economic growth model introduced a new factor, knowledge (technology), rather than leaving it as an undetermined residual, the 'invisible hand' as had been the case in the Solow's neoclassical model (Romer 1986; Lucas 1988). In this scenario, the role of university has been understood as a provider of knowledge (technology) with its innovative context as an important source of economic growth. As noted by the European Commission, "The fast development of the Information and Communication Technology (ICT) has brought about deep changes in our way of working and living, as the widespread diffusion of ICT is accompanied by organizational, commercial, social and legal innovations".

Following this perspective, the society is identified as the Information Society, a society in which low-cost information and ICT is in general use, or as the Knowledge(-based) Society, to stress the fact that the most valuable asset is investment in intangible, human, and social capital and that the key factors are knowledge and creativity. ${ }^{4}$ This new society is characterized by the accelerating pace at which knowledge is created and by the development of knowledge-based communities and regions where networks of researchers produce and exchange new knowledge which is commercialized by entrepreneurs and established firms. Knowledge and innovation are increasingly the key to competitiveness, economic growth and wealth creation in our globalized and competitive world (Mian 2011). The society is challenging the traditional university model and functions with its demands for new professions and qualifications, the increasing variety of people coming to study, the growing complexity and speed of knowledge, and the expectation that universities should contribute both to the generation of knowledge (a traditional function) and to its transfer to the business world for commercialization and the good of society-(a new function) (Mian et al. 2012). Under these assumptions, the new knowledge would automatically spillover for commercialization resulting in innovative activity and ultimately economic growth.

The innovation literature recognizes the role of universities on innovation traditionally by important channels such as the development of spin-off firms, patents, licenses but also by the strong indirect relationship such as supplier of knowledge via trained graduates, publications, and consulting (Klofsten and Jones Evans 2000; Cohen et al. 2002). Indeed, the best example of university relevance is the Bayh-Dole Act where the US government implemented a policy for

\footnotetext{
${ }^{4}$ For further information, please visit http://ec.europa.eu/ employment_social/knowledge_society/index_en.htm.
} 
Table 1 Selected special issues published regarding entrepreneurial universities Source Authors

\begin{tabular}{|c|c|c|c|}
\hline Year & Journal & Guest-Editor(s) & Title \\
\hline 2001 & $\begin{array}{l}\text { Journal of Technology } \\
\text { Transfer, 26(1-2) }\end{array}$ & $\begin{array}{l}\text { D.Siegel; J.G. Thursby; M. Thursby; A. } \\
\text { Ziedoni }\end{array}$ & $\begin{array}{l}\text { Organizational Issues in University-Industry } \\
\text { Technology Transfer: An Overview of the } \\
\text { Symposium Issue }\end{array}$ \\
\hline 2002 & $\begin{array}{l}\text { Journal of Business Venturing, } \\
17(6)\end{array}$ & Shane, S. & $\begin{array}{l}\text { University technology transfer to entrepreneurial } \\
\text { companies }\end{array}$ \\
\hline 2002 & Management Science, 48(1) & D. Mowery; S. Shane & $\begin{array}{l}\text { University entrepreneurship \& Technology } \\
\text { transfer }\end{array}$ \\
\hline 2003 & $\begin{array}{l}\text { Journal of Technology } \\
\text { Transfer, 28(1) }\end{array}$ & D. Siegel; B. van Pottelsberghe & $\begin{array}{l}\text { Economic and Managerial Implications of } \\
\text { University Technology Transfer }\end{array}$ \\
\hline 2003 & Research Policy, 32(2) & S.Shane; S Venkataraman & $\begin{array}{l}\text { Guest editors' introduction to the special issue } \\
\text { on technology entrepreneurship }\end{array}$ \\
\hline 2005 & $\begin{array}{l}\text { Journal of Business Venturing, } \\
\text { 20(2) }\end{array}$ & P. Phan; D. Siegel, M. Wright & $\begin{array}{l}\text { Science parks and incubators: observations, } \\
\text { synthesis and future research }\end{array}$ \\
\hline 2005 & Research Policy, 34(7) & $\begin{array}{l}\text { A. Lockett, D. Siegel, M. Wright and } \\
\text { M.D. Ensley }\end{array}$ & $\begin{array}{l}\text { The Creation of Spin-off Firms at Public } \\
\text { Research Institutions: Managerial and Policy } \\
\text { Implications }\end{array}$ \\
\hline 2009 & $\begin{array}{l}\text { Strategic Entrepreneurship } \\
\text { Journal, 3(4) }\end{array}$ & Cumming, D.; Siegel, D.; Wright, M. & $\begin{array}{l}\text { International entrepreneurship: managerial and } \\
\text { policy implications }\end{array}$ \\
\hline 2011 & $\begin{array}{l}\text { International Journal of } \\
\text { Entrepreneurship and Small } \\
\text { Business, 12(4) }\end{array}$ & Dowling, M. & Special Issue on Academic Entrepreneurship \\
\hline 2011 & Research Policy, 40(8) & $\begin{array}{l}\text { Grimaldi, R.; Kenney, M.; Siegel, D.; } \\
\text { Wright, M. }\end{array}$ & $\begin{array}{l}30 \text { years after Bayh-Dole: Reassessing } \\
\text { Academic Entrepreneurship }\end{array}$ \\
\hline 2012 & Research Policy, 41(7) & $\begin{array}{l}\text { Fagerberg, J., Landström, H. and } \\
\text { Martin, B. }\end{array}$ & $\begin{array}{l}\text { Exploring the Emerging Knowledge Base of } \\
\text { 'The Knowledge Society }\end{array}$ \\
\hline 2013 & $\begin{array}{l}\text { Journal of Business Venturing, } \\
28(1)\end{array}$ & $\begin{array}{l}\text { P. Devereaux Jennings, Royston } \\
\text { Greenwood, Michael D. Lounsbury } \\
\text { and Roy Suddaby }\end{array}$ & Institutions, Entrepreneurs, Community \\
\hline 2015 & Technovation, 50-51 & $\begin{array}{l}\text { Sarfraz Mian, Wadid Lamine, Alain } \\
\text { Fayolle }\end{array}$ & Technology Business Incubation Mechanisms \\
\hline
\end{tabular}

fostering and funding university innovation (Grimaldi et al. 2011). Then, universities have played an important and historic role in innovation within the National Innovation Systems (NIS). In particular, their combined performance of advance research, knowledge networks, and training is an important source of the university contributions to economic growth (Huggins and Kitagawa 2012; Guerrero et al. 2015). For this reason, literature on innovation placed universities at the heart of any national innovation systems (Cooke et al. 1997; Asheim et al. 2011).

\subsection{Entrepreneurial university as a driver of entrepreneurial contexts}

Audretsch and Keilbach (2004) introduced a new factor, entrepreneurial activity and linked it to output in the context of a production function model. It explains how some contexts generating a high propensity for economic agents to start new firms can be characterized as being rich in entrepreneurial activity, while other contexts, where the startup of new firms is inhibited, can be characterized as being weak in entrepreneurial activity. Entrepreneurial activity therefore can contribute to output and growth by serving as a conduit for knowledge spillovers, increasing competition, and by injecting diversity. According to OECD, 'entrepreneurs are agents of change and growth in a market economy and they can act to accelerate the generation, dissemination and application of innovative ideas... Entrepreneurs not only seek out and identify potentially profitable economic opportunities but are also willing to take risks to see if their hunches are right' (OECD 1998, p. 11). 
The determinants of entrepreneurship are shaped by a number of forces and factors, including legal and institutional but also social factors as well (Fayolle 2007; Herrmann et al. 2012). Therefore, in an Entrepreneurial Society, institutions are created and modified to facilitate entrepreneurial activity which severs as the driving force underlying economic growth and prosperity (Audretsch 2007). Thus, universities facilitate the entrepreneurial driven economic growth through an institutional context which is conducive to entrepreneurial activity. Audretsch (2014) further argues that the role of universities is more than generating technology transfer (patents, spin-offs and start-ups), and rather, contribute and provide leadership for creating entrepreneurial thinking, actions, institutions and entrepreneurial capital (Gibb and Hannon 2006). In this sense, a dichotomy emerges for the entrepreneurial university with certain parts of the university contributing as innovation driver while other parts contributing as entrepreneurship driver (Guerrero and Urbano 2014; Guerrero et al. 2015, 2016; Svensson et al. 2012). Under this perspective and in line with the NIS' literature, the literature of entrepreneurial ecosystems also recognizes the role of entrepreneurial universities on the creation and development of entrepreneurship (Isenberg 2010). For instance, in the entrepreneurial ecosystem, universities have strong contributions proving talent human capital (intrapreneurs, entrepreneurs, employees), supporting the entrepreneurial culture (values and attitudes toward educational programmes) and building/supporting inter-relationships/linkages among entrepreneurs, venture capitalists, business incubators, and other actors (Mason and Brown 2014).

\subsection{Entrepreneurial university as a driver of innovation and entrepreneurship in the new social and economic landscape}

As we can see, both the innovation and entrepreneurship literature recognize the relevant role of universities and in some way considered it such as the key actor or linkage among all the actors involved in the ecosystems. In this regards, Zahra and Wright (2011) argue that the innovation literature, and especially, the National System Innovation (NSI) literature was mostly about structure and institutions, while the entrepreneurship literature has been mostly about the individual or the firm. On one hand, NSI focused on the complex relationships of cooperation, communication, and feedback among institutions in both the process of innovation and the innovative performance across countries (Carlsson et al. 2002). This orientation has been criticized because the existing literature provides only limited insights into the drivers and on mechanisms that can explain their evolution and growth over time (Castellacci and Natera 2013). On the other hand, the entrepreneurship literature traditionally focused on independent ventures as well as on the organizational mode within which entrepreneurial initiatives took place-intrapreneurship-(Parker 2011). Based on this theoretical gap, Autio et al. (2014) propose the concept of entrepreneurial innovation ecosystems to distinguish between different types of contexts that influences on it such as industrial, organizational, institutional, and social contexts overlaid by temporal and spatial contexts.

In this sense, an entrepreneurial and innovation ecosystem could be understood as a set of interconnected actors (potential and existing), entrepreneurial organizations (e.g., firms, venture capitalists, business angels, banks, public sector agencies), innovative organizations (e.g., universities, research centers), and entrepreneurial and innovative processes (e.g., business birth, high growth firms, serial entrepreneurs, degree of entrepreneurial and innovative mentality within firms, and levels of ambition) which formally and informally coalesce to connect, mediate by the government initiatives oriented to the performance of the local entrepreneurial environment (Mason and Brown 2014, p. 5). Generally, entrepreneurial and innovation ecosystem emerges in locations that have place-specific assets/attributes. It represents a shift from traditional economic thinking on firms/markets (management societies) to new economic thinking involving different agents in the society, market, and organizations (entrepreneurial societies) (Audretsch and Thurik 2004). Typically, successful ecosystems have emerged under a unique set of pre-existing circumstances as well as with conditions subsequently created. For instance, Isenberg (2010) identified certain pillars that comprise a successful entrepreneurial innovation ecosystem, including accessible markets (both domestic and foreign), talented human capital and a qualified workforce, access to private/ public sources of funding, an adequate support system and regulatory frameworks, and cultural support, 
among others. Nevertheless, these optimal conditions or pillars are not present in all types of economies.

As a result, an increased importance and significance of the university in terms of its impact on the economy are observed within the knowledge and entrepreneurial economy (Audretsch 2014). As universities are located on the intersection of education, research, and transfer of knowledge, they are considered a key access agent in any entrepreneurship and innovation ecosystems. Traditionally, universities tend to be large organizations that by nature are not very entrepreneurial in their focus; however, the incorporation of an entrepreneurial orientation into a university's missions could change this convention (Kirby et al. 2011). The core activities of universities have been universally recognized as teaching and research, but currently universities have undergone internal transformations in order to adapt to external conditions and to legitimize their role in the economy, giving birth to a new kind of university: the entrepreneurial university (Guerrero and Urbano 2012, 2014; Guerrero et al. 2015, 2016). Based on this perspective, this special issue is focused on Entrepreneurial Universities in their regional context and addresses the effectiveness of their innovative entrepreneurial orientation in meeting regional economic and societal needs, in a sustainable way. More specifically, an Entrepreneurial University is being considered as an organization that adopts an entrepreneurial management style, with its members (faculty, students, and staff) acting entrepreneurially and that intern interacts with its outside environment (community/ region) in an entrepreneurial manner (Clark 2001; Klofsten and Jones-Evans 2000). However, traditional studies of entrepreneurial university tend to take a narrow view of industry-university relations focusing on the commercialization of research results and on mechanisms of technology transfer such as science parks and incubators, liaison offices, or intellectual property (O'Shea et al. 2005; Wright et al. 2007; Grimaldi et al. 2011).

By its very nature, the heterogeneity of an organization will result in varying views on nearly any subject. Universities are no exception, nor are the areas of innovation and entrepreneurial support. Supervisors, research groups, departments, and central university management will differ on how best the university should channel its efforts to become an entrepreneurial institution. Thus, crafting a strategy to achieve this requires knowledge of how academics perceive support at various levels in the institution. Studies usually cite the human element, such as opinions on commercialization and the capacities of the participants for entrepreneurship, as well as their experience and team membership, as factors affecting academic entrepreneurship (Fini et al. 2009; Bienkowska and Klofsten 2012). Newer research is investigating the institutional environment and its influence on academic entrepreneurship. The hope is to discover whether and to what extent differences in the practice, interpretation, and support of commercialisation occur among various university actors. Studies have noted that entrepreneurial involvement can vary widely between departments at a university (Bercovitz and Feldman 2008; Bienkowska et al. 2016).

Thus, the local environment, with its unique mix of cultures, history, and canons, exerts a greater or lesser influence on the entrepreneurial efforts of faculty (Kenney and Goe 2004) due to the peer effect. Individuals are more comfortable following the established behaviors and norms of their immediate surroundings. For example, it has been observed that when department chairs set a trend of making new inventions public, other faculty members tend to follow suit (Bercovitz and Feldman 2008). Other researchers have noted that entrepreneurial behavior among academic peers is closely linked with their perception of role models and is empirically measurable (Prodan and Drnovsek 2010). In Davies' perspective (2001), entrepreneurial culture at institutions was more holistically depicted when relations between central management, the department, and the individual, as well as the plasticity of the organization that allowed collective learning, changing rules, and structures, is also considered. Such involvement and commercialisation among academics are not restricted to one level but is influenced by the interplay of individual, organizational, and institutional factors (Perkmann et al. 2013). Organizational support appeared to be more important than academic engagement for encouraging commercialisation activities (Perkmann et al. 2013). So, how academics with entrepreneurial intentions perceive university support at various levels may be determining for their decision to pursue entrepreneurial projects (Rasmussen and Borch 2010). Because such perceptions may affect actual behavior and because the literature found the best predictor of entrepreneurial behavior to be intention, a better understanding of perceived support 
and its impact on behavior and intention is warranted (Krueger et al. 2000).

\section{Insights into the emerging entrepreneurial university models in the USA and Europe: The contributions of this special issue}

The papers included in this special issue contribute to the entrepreneurship literature in two different ways. First, there is the debate of interactions between individuals (students, researchers, scientists) and organizations (entrepreneurial university) oriented to develop new models that meet social/economic targets of fostering innovation/entrepreneurship. Second there is the debate of interactions between organizations (entrepreneurial universities) and other agents (intermediaries, government entities ...) enrolled in the development of new models for fostering innovation/entrepreneurship and producing socio-economic effects in the regions/countries.

\subsection{Individual and organizational level: reorientation of entrepreneurial university' strategies}

\subsubsection{Students' entrepreneurship engagement and university internationalization in Europe}

According to Minola et al. (2016), several strategical and organizational issues have been discussed in the transformation process of making universities more entrepreneurial. However, the role of internationalization has been misunderstood in the academic debate of emerging universities models (Knight 2015). This issue plays a particular interest in the current socioeconomic scenario because the contribution of internationalization is crucial for the competitiveness of each type of organization (Knight 2004). Adopting the basis of internationalization theory and using a multilevel analysis with data from 25,855 students enrolled in 130 European Universities, Minola et al. (2016) analyze the effect of university internationalization on students' progressive engagement in entrepreneurship, as well as, along the core entrepreneurial university missions (teaching, research, and socio-economic contribution). These authors found that the internationalization strategy has a positive direct effect on the European students' level of engagement in entrepreneurship, as well as, acts as a moderator of the relationship between entrepreneurial university' supports and the students' level of engagement in entrepreneurship. In this regards, Minola et al.'s paper contributes to the debate of the new strategies adopted by European entrepreneurial universities to meet the demands of the emerging knowledge and entrepreneurial society. This study not only provides evidence about the effect of internationalization in European universities but also propose alternative measures or proxies to explore the European entrepreneurial universities' outcomes that could be replicated in other environments.

\subsubsection{Researchers' attributes and TTOs awareness in Europe}

In the development of entrepreneurial universities, the authors have identified several internal/external factors that facilitate the transition process from traditional to the entrepreneurial university mode (Kirby et al. 2011). One of them has been the use of technology transfer offices (TTOs) that foster links between industry and university, as well as, commercialize university's knowledge (Perkmann et al. 2013). However, according to Huyghe et al. (2016), researchers may not always purposefully bypass the TTO when they decide to commercially exploit their research because sometimes they take their inventions directly to the market. In this sense, Huyghe et al.'s paper investigates the impact of a series of individuals attributes on TTO awareness. Adopting information processing theory, authors test their proposed model using data from 3250 researchers enrolled in 24 European universities. The evidence confirms that a small portion of researchers is actually aware of the existence of TTO at their universities, and that the TTO awareness is higher among researchers with prior entrepreneurial experience, with contracts with external agents. In this regards, Huyghe et al.'s paper contributes to the debate about the interaction among individual and organizational factors identifying those who make more(less) difficult the commercial exploitation.

\subsubsection{Researchers' opportunist behavior within US entrepreneurial universities}

According to Gianiodis et al. (2016), the study of entrepreneurial universities is not only important in its 
own right, but also advance agency theory by assessing key conditions under which university scientists act opportunistically. It means that the entrepreneurial university (principal) may not always capture the full gains made by the broader economy due to the opportunist behavior of its scientists (agent). This agent's behavior persists in the face of substantial information asymmetry and where the principal appears to tolerate despite their ability to sanction. Based on these arguments, Gianiodis et al.'s paper tries to demonstrate that some scientists privately leak discoveries invented while working for their entrepreneurial universities. Using a sample of 73,603 scientists across 105 US universities, the authors show that overt opportunism occurs even in the presence of monitoring, incentivizing, and high stakes and that universities are unable to confront scientists who are seen to violate their employment contracts. In this regards, Gianiodis et al. (2016) contribute to the entrepreneurial universities' literature opening the debate in which university administrators appear non-reactive when their agents act opportunistically, as well as, in the conditions that either exacerbate or reduce agents' overt opportunism.

\subsection{Organizational and regional level:} entrepreneurial university's initiatives, outcomes and impacts in the region

\subsubsection{Structuring entrepreneurial university ecosystem within an US state}

Shane (2004) argues that one important contribution of the entrepreneurial university is related to the creation of new spin-offs; it is a window of socioeconomic contributions to the region (Guerrero et al. 2015, 2016). As a result, the entrepreneurial university develops several initiatives to support faculty and graduates' spin-off companies based on university research. In this sense, entrepreneurial universities need to develop strategic and collective actions with the help of intermediaries to maximize their both entrepreneurial and innovation contributions (Hayter 2016). However, little research exists that conceptualize the structure and function of an entrepreneurial university ecosystem. Based on these arguments, Hayter's paper examines the composition, function, and evolution of social networks among faculty/ students and intermediaries. Adopting networks literature/methodologies and using data from universities within New York, the author finds that academic entrepreneurs are limited by their own homophilous social networks but also that their success relies upon academic and non-academic contacts that connect faculty/students to other social networks. In this regards, Hayter's paper contributes to the debate about the importance of organizational 'cross logics' for obtaining valuable resources/contacts within the context of academic entrepreneurship, highlighting the contribution and evolution of intermediary networks.

\subsubsection{Associating intensity and performance of knowledge of entrepreneurial university across UK regions}

According to Zhang et al. (2016), extant studies have examined the best practices of entrepreneurial knowledge exchange activities within higher education sector. However, there is a lack of recognition of the difficulty of transplanting models of entrepreneurial universities engagement with business and society from successful regions to weaker regions. Based on these arguments, Zhang et al.'s paper tries to shed light on the nature of different entrepreneurial activities through the prism of competitive (successful regions) and uncompetitive (weaker regions) to provide a better understanding about the role of entrepreneurial universities on the regional development. Using data from $12 \mathrm{UK}$ regions, the authors find that uncompetitive regions are more intensely engaged in entrepreneurial activities but generate less outcomes than competitive regions, as well as, academic knowledge is more strongly bounded within a certain distance in weaker regions, while geographical distance seems less of a hindrance to academics in successful regions. In this regards, Zhang et al.'s paper contributes to the debate of entrepreneurial universities' impacts on socio-economic development, as well as providing insights into the relevance of exchanging knowledge across diverse regions.

\subsubsection{Evaluating the causal effect of $R \& D$ on patenting activity in Sweden}

Ejermo and Källström (2016) argue that the general responsiveness to $R \& D$ is found to be higher in Sweden universities than corresponding estimates in US studies; especially, when are adopted instrumental variable techniques that address endogeneity in the R\&D-to-patent relationship. Prior studies have 
Table 2 Potential research question associated to the contributions of this special issue Source Excerpted from the papers included in this special issue

\begin{tabular}{|c|c|c|}
\hline Levels & Questions explored in this special issue & Potential research questions \\
\hline \multirow[t]{3}{*}{$\begin{array}{l}\text { Individual-Organizational } \\
\text { interactions }\end{array}$} & $\begin{array}{l}\text { Using the internationalization theory, Minola } \\
\text { et al.'s recognize that there is not a standardized } \\
\text { model of the university internationalization as } \\
\text { well as it is necessary to understand the influence } \\
\text { of contextual factors across the level of } \\
\text { development of each economy (Knight 2015) }\end{array}$ & $\begin{array}{l}\text { What are the theoretical foundations and empirical } \\
\text { evidence about the connection between the } \\
\text { internationalization strategy and the } \\
\text { entrepreneurial university role as a driver of } \\
\text { innovation/entrepreneurship activity? }\end{array}$ \\
\hline & $\begin{array}{l}\text { Using diverse theories, Huyghe et al.'s paper } \\
\text { explored the connection among European } \\
\text { academics' characteristics and TTO awareness. } \\
\text { However, there is need to continue expanding } \\
\text { theoretically and empirically this relationship to } \\
\text { understand the success of both academics and } \\
\text { university initiatives }\end{array}$ & $\begin{array}{l}\text { What individual characteristics determinate the } \\
\text { propensity to use or not use the mechanisms } \\
\text { developed by the university to foster innovation/ } \\
\text { entrepreneurship activities? It may also help to } \\
\text { explore the level of success of spin-offs and } \\
\text { university contributions to socioeconomic } \\
\text { development }\end{array}$ \\
\hline & $\begin{array}{l}\text { Using the agency theory, Gianiodis et al.'s paper } \\
\text { explored the overt opportunism behavior of US } \\
\text { scientists. However, there is necessary to } \\
\text { continue exploring the effects and impacts of } \\
\text { those behaviors in diverse contexts }\end{array}$ & $\begin{array}{l}\text { What are the theoretical foundations and empirical } \\
\text { evidence about the impact of opportunist } \\
\text { behavior on the entrepreneurial university's role } \\
\text { as a driver of innovation/entrepreneurship } \\
\text { activity? }\end{array}$ \\
\hline \multirow[t]{4}{*}{$\begin{array}{l}\text { Organizational- } \\
\text { Regional/country } \\
\text { interactions }\end{array}$} & $\begin{array}{l}\text { Using network theory, Hayter's paper provides } \\
\text { insights about the structure and performance of } \\
\text { New York's entrepreneurial universities } \\
\text { ecosystems }\end{array}$ & $\begin{array}{l}\text { What are the main interests behind the } \\
\text { interactions/networks among the agents involved } \\
\text { in the entrepreneurial innovation system? What } \\
\text { are the potential outcomes/impacts of those } \\
\text { interactions across regions/countries? }\end{array}$ \\
\hline & $\begin{array}{l}\text { Using a regional analysis, Zhang et al.'s paper } \\
\text { recognized the lack in the difficulty of } \\
\text { transplanting models of entrepreneurial } \\
\text { universities' engagement with business and } \\
\text { society in weaker regions in comparison with the } \\
\text { successful regions }\end{array}$ & $\begin{array}{l}\text { What are the theoretical foundations and empirical } \\
\text { evidence about the relationships among } \\
\text { entrepreneurial university's outreach activities } \\
\text { and the level of regional development (and vice } \\
\text { versa)? }\end{array}$ \\
\hline & $\begin{array}{l}\text { Using diverse theories, Ejermo and Källström's } \\
\text { paper explored the causal relationships among } \\
\text { R\&D and patenting activity in Swedish } \\
\text { universities. However, it is also important to } \\
\text { explore the quality of entrepreneurial/innovative } \\
\text { initiatives in supporting environments }\end{array}$ & $\begin{array}{l}\text { What are the theoretical foundations and measures } \\
\text { to evaluate the effect of government support on } \\
\text { the quantity/quality of patenting activities and } \\
\text { their socioeconomic impact? }\end{array}$ \\
\hline & $\begin{array}{l}\text { Using institutional theory, Abreu et al.'s paper } \\
\text { recognizes the necessity to advance } \\
\text { methodologies to provide insights about the } \\
\text { socio-economic impact on different geographical } \\
\text { regions }\end{array}$ & $\begin{array}{l}\text { What are the theoretical foundations, measures } \\
\text { and robust methodologies to explore the } \\
\text { translation of innovative/entrepreneurship } \\
\text { university activities into socio-economic } \\
\text { development? }\end{array}$ \\
\hline
\end{tabular}

estimated this relationship using US data, however, little is known about this relationship in a context where the academics are privileged and receive strong support such as in Sweden where government provide several grants for those who are involved in patenting activities. Using a panel data for the period of 1995-2000, Ejermo and Källström's paper contributes to the entrepreneurial universities debate about how academics respond more strongly to $R \& D$ resources in supportive environments (Sweden) than in other reference environments (USA).

\subsubsection{Exploring the impacts of UK university activities}

The Abreu et al. (2016) paper deals with increased pressure on universities to deliver on their third mission (e.g., in the UK context). In this sense, the 
Table 3 Additional research agenda Source Authors

\begin{tabular}{lc}
\hline Levels & Potential research questions \\
\hline $\begin{array}{l}\text { Individual-Organizational } \\
\text { interactions }\end{array}$ & How entrepreneurial universities' actions or strategies adapt to new challenges presented by \\
heightened environmental turmoil? \\
What are the environmental factors (i.e., formal: policies, incentives \& informal: attitudes, \\
culture) and internal factors (i.e., resources and capabilities), that affect the development of \\
Entrepreneurial Universities in the new social and economic landscape? \\
What is the relationship between research and teaching at Entrepreneurial Universities, including \\
adaptation of curricula in degree programs and in continuing education to include new \\
knowledge and meet regional needs? How is it done? What is its impact on regional innovation? \\
Are faculty's university-industry engagements mechanisms are more effective than traditional \\
commercialization support mechanisms? \\
What is the role of Entrepreneurial Universities as drivers and/or contributors to innovative and \\
entrepreneurial contexts of development? \\
Which of their activities are directly linked to regional/national development? \\
What are the best dependent variables/performance metrics to assess Entrepreneurial University \\
outcomes and socio-economic impacts? \\
How are Entrepreneurial Universities adapting to meet the demands of the emerging knowledge \\
and entrepreneurial society? \\
What is the most effective mix of Entrepreneurship and Innovation in an Entrepreneurial \\
University to meet societal needs and for positive regional impact?
\end{tabular}

paper provides an analysis of entrepreneurial activities in teaching-led universities in comparison with their research-intensive counterparts. Adopting the institutional approach and using data from 22,000 academics across all UK universities, the authors find that proportion of academics engaged in licensing and spinout activities is higher in research-intensive universities, and the same is true for problem-solving activities overall, although there are some types of activities for which the engagement gap is much less pronounced. Based on these findings, Abreu et al.'s paper contributes to the analysis of entrepreneurial university outcomes by diverse types of universities, fields, and geographical locations.

\section{Research agenda for further research in entrepreneurial university}

\subsection{Potential research questions}

Based on the findings and contributions of this special issue, some potential research questions associated with the issues explored about the entrepreneurial university phenomenon are listed in Table 2.
While looking at our initial call for this special issue, we find that several research questions remain unaddressed (Table 3). Therefore, we propose some additional research questions that would be interesting to explore in diverse socio-economic scenarios (not only in developed but also in emerging and the transition economies).

\subsection{Implications}

From this special issue emerge several implications for university managers, agents involved in the innovation/entrepreneurial ecosystems, and policy makers. Firstly, for higher education managers, the studies evidenced the models, the outcomes and the impacts of supporting entrepreneurship and innovation as a part of USA and European entrepreneurial universities' strategies. These models are relying on university community and policy makers to spread the advantages as drivers of entrepreneurship and innovation initiatives. In addition, the studies provide evidence about the relevance of taking into account individuals' characteristics when they define/implement initiatives to enhance innovation/entrepreneurship such as enhance the visibility of them among the 
university community, as well as, consider the incorporation of measures to capture the outcomes/impacts of those initiatives. Moreover, the studies also provide arguments about the debate in the management of entrepreneurial universities activities. It is clear that by facilitating innovation/entrepreneurship and regional benefits universities not only enhance their reputation but also the reputation of their university community (students, academics/scientists). Therefore, it is a necessary mechanism to manage the innovation/entrepreneurship functions along with understanding the innovators/entrepreneurs behaviors of overt opportunism. Secondly, for entrepreneurial/ innovation agents in the system, the studies offer insights about the strategies implemented by USA and European entrepreneurial universities for bridging networks to create and achieve academic entrepreneurship outcomes/success that is transferred to the society. In this regard, it is interesting to explore models/channels that reinforce their cooperation and outcomes. Thirdly, for policy makers, the studies evidence the necessity of an entrepreneurial and innovation strategy where the involvement of universities such an agent of the entrepreneurial/innovation ecosystems will be recognized/legitimized. It requires the implementation of indicators/measures that allows comparisons of the results across universities, regions, countries. For instance, there are interesting initiatives in the USA and UK that are implemented by certain universities/regions, but they need to be translated to other universities/regions. Finally, the studies also provide evidence about the positive effect of government support for innovation/entrepreneurship activity at the university. It also brings insights about the best practices/models that could be adapted/evaluated/translated into other regions.

\section{Conclusion}

This special issue focused on emerging models of entrepreneurial universities in the new socio-economic landscape. In this introductory article, we have argued the relevance of entrepreneurial universities in the development of innovation and entrepreneurship activities and benefitted from the national innovation systems' (NIS) and the emerging entrepreneurship ecosystems' literature. The variety of papers included in this special issue addresses different aspects of the individual-organizational interactions, as well as, the organizational-regional context interactions in the USA and European scenarios. The agenda we outlined for future research on the role of entrepreneurial universities as drivers of innovation and entrepreneurship proposes to fill gaps in this field of study. The wide variety of themes and the questions asked show that this topic is a promising area of future research. To answer these questions, we would need more systematic data not only from the developed economies but also in other transitional/emerging economies. We also anticipate a shift in theoretical and methodological approaches to explore this phenomenon. To address the unanswered questions, particularly in varied regional settings and to entertain novel methodological approaches employing new theoretical lenses, shall warrant the need for another special issue in the near future. We hope that the directions proposed in this special issue will inspire many colleagues to enrich our understanding of the role of entrepreneurial universities in stimulating entrepreneurship and innovation.

Acknowledgments The Guest Editors of the Special Issue acknowledge the support provided by David Audretsch, Editorin-Chief, Small Business Economics. We also appreciate the time and hard work of many colleagues who volunteered to review the manuscripts and offered valuable advice to the authors (confidentiality rules do not permit to list their names).

\section{References}

Abreu, M., Demirel, P., Grinevich, V., \& Karatas-Ozkan, M. (2016). Entrepreneurial practices in research-intensive and teaching-led universities. Small Business Economics. doi:10.1007/s11187-016-9754-5.

Asheim, B. T., Smith, H. L., \& Oughton, C. (2011). Regional innovation systems: Theory, empirics and policy. Regional Studies, 45(7), 875-891.

Audretsch, D. B. (2007). The entrepreneurial society. USA: Oxford University Press.

Audretsch, D. B. (2014). From the entrepreneurial university to the university for the entrepreneurial society. The Journal of Technology Transfer, 39(3), 313-321.

Audretsch, D., \& Keilbach, M. (2004). Entrepreneurship capital and economic performance. Regional Studies, 38(8), 949-959.

Audretsch, D., \& Thurik, R. (2004). A model of the entrepreneurial economy. International Journal of Entrepreneurship Education, 2(2), 143-166.

Autio, E., Kenney, M., Mustar, P., Siegel, D., \& Wright, M. (2014). Entrepreneurial innovation: The importance of context. Research Policy, 43(7), 1097-1108. 
Bercovitz, J., \& Feldman, M. (2008). Academic entrepreneurs: Organizational change at the individual level. Organization Science, 19(1), 69-89.

Bienkowska, D., \& Klofsten, M. (2012). Creating entrepreneurial networks: Academic entrepreneurship, mobility and collaboration during $\mathrm{PhD}$ education. Higher Education, 64(2), 207-222.

Bienkowska, D., Klofsten, M., \& Rasmussen, E. (2016). PhD students in the entrepreneurial university-perceived support for academic entrepreneurship. European Journal of Education, 51(1), 56-72.

Brown, R., \& Mason, C. (2014). Inside the high-tech black box: A critique of technology entrepreneurship policy. Technovation, 34(12), 773-784.

Busenitz, L. W., Plummer, L. A., Klotz, A. C., Shahzad, A., \& Rhoads, K. (2014). Entrepreneurship research (1985-2009) and the emergence of opportunities. Entrepreneurship Theory and Practice, 38(5), 981-1000.

Carlsson, B., Jacobsson, S., Holmén, M., \& Rickne, A. (2002). Innovation systems: Analytical and methodological issues. Research Policy, 31(2), 233-245.

Castellacci, F., \& Natera, J. M. (2013). The dynamics of national innovation systems: A panel cointegration analysis of the coevolution between innovative capability and absorptive capacity. Research Policy, 42(3), 579-594.

Charles, D., Kitagawa, F., \& Uyarra, E. (2014). Universities in crisis? - new challenges and strategies in two English cityregions. Cambridge Journal of Regions, Economy and Society, 7(2), 327-348.

Clark, B. (2001). The entrepreneurial university: New foundations for collegiality, autonomy, and achievement. Higher Education Management, 13(2), 9-24.

Cohen, W. M., Nelson, R. R., \& Walsh, J. P. (2002). Links and impacts: The influence of public research on industrial R\&D. Management Science, 48(1), 1-23.

Cooke, P., Uranga, M. G., \& Etxebarria, G. (1997). Regional innovation systems: Institutional and organisational dimensions. Research Policy, 26(4), 475-491.

Corona, L., Doutriaux, J., \& Mian, S. (2006). Building knowledge regions in North America: Emerging technology innovation poles. Elgar: Edward.

Cunningham, J. A., \& Link, A. N. (2015). Fostering universityindustry R\&D collaborations in European Union countries. International Entrepreneurship and Management Journal, 11(4), 849-860.

Ejermo, O., \& Källström, J. (2016). What is the causal effect of $\mathrm{R} \& \mathrm{D}$ on patenting activity in a "Professor's Privilege" country? Evidence from Sweden. Small Business Economics. doi:10.1007/s11187-016-9752-7.

Etzkowitz, H., \& Leydesdorff, L. (2000). The dynamics of innovation: From National Systems and "Mode 2" to a Triple Helix of university-industry-government relations. Research Policy, 29(2), 109-123.

Etzkowitz, H., Webster, A., Gebhardt, C., \& Terra, B. R. C. (2000). The future of the university and the university of the future: Evolution of ivory tower to entrepreneurial paradigm. Research Policy, 29(2), 313-330.

Fayolle, A. (2007). Entrepreneurship and new value creation: The dynamic of the entrepreneurial process. Cambridge: Cambridge University Press.
Fini, R., Grimaldi, R., \& Sobrero, M. (2009). Factors fostering academics to start up new ventures: An assessment of Italian founders' incentives. Journal of Technology Transfer, 34(4), 380-402.

Gianiodis, P. T., Markman, G. D., Panagopoulos, A. (2016). Entrepreneurial universities and overt opportunism. Small Business Economics. doi:10.1007/s11187-016-9753-6.

Gibb, A., \& Hannon, P. (2006). Towards the entrepreneurial university. International Journal of Entrepreneurship Education, 4(1), 73-110.

Grimaldi, R., Kenney, M., Siegel, D., \& Wright, M. (2011). 30 years after Bayh-Dole: Reassessing academic entrepreneurship. Research Policy, 40(8), 1045-1057.

Guerrero, M., \& Urbano, D. (2012). The development of an entrepreneurial university. The Journal of Technology Transfer, 37(1), 43-74.

Guerrero, M., \& Urbano, D. (2014). Academics' start-up intentions and knowledge filters: An individual perspective of the knowledge spillover theory of entrepreneurship. Small Business Economics, 43(1), 57-74.

Guerrero, M., Cunningham, J. A., \& Urbano, D. (2015). Economic impact of entrepreneurial universities' activities: An exploratory study of the United Kingdom. Research Policy, 44(3), 748-764.

Guerrero, M., Urbano, D., \& Fayolle, A. (2016). Entrepreneurial activity and regional competitiveness: Evidence from European entrepreneurial universities. The Journal of Technology Transfer, 41(1), 105-131.

Hayter, C. (2016). A trajectory of early-stage spin-offs success: The role of knowledge intermediaries within an entrepreneurial university ecosystem. Small Business Economics. doi:10.1007/s11187-016-9756-3.

Herrmann, B., Marmer, M., Dogrultan, E. y Holtschke, D. (2012). Start-up Ecosystem Report 2012. Part One. Startup Genome's Start-up Compass sponsored by Telefónica. Obtenida el 9 de enero de 2013, de http://reports. startupcompass.co/

Huggins, R., \& Kitagawa, F. (2012). Regional policy and university knowledge transfer: Perspectives from devolved regions in the UK. Regional Studies, 46(6), 817-832.

Huyghe, A., Knockaert, M., Piva, E., \& Wright, M. (2016). Are researchers deliberately bypassing the technology transfer office? An analysis of TTO awareness. Small Business Economics. doi:10.1007/s11187-016-9757-2

Isenberg, D. J. (2010). How to start an entrepreneurial revolution. Harvard Business Review, 88(6), 40-50.

Kenney, M., \& Goe, R. W. (2004). The role of social embeddedness in professorial entrepreneurship: A comparison of electrical engineering and computer science at UC Berkeley and Stanford. Research Policy, 33(5), 691-707.

Kirby, D. A., Guerrero, M., \& Urbano, D. (2011). Making universities more entrepreneurial: Development of a model. Canadian Journal of Administrative Sciences/Revue Canadienne des Sciences de l'Administration, 28(3), 302-316.

Klofsten, M., \& Jones-Evans, D. (2000). Comparing academic entrepreneurship in Europe-The case of Sweden and Ireland. Small Business Economics, 14(4), 299-310.

Knight, J. (2004). Internationalization remodeled: Definition, approaches, and rationales. Journal of studies in international education, 8(1), 5-31. 
Knight, J. (2015). International universities misunderstandings and emerging models? Journal of Studies in International Education, 19(2), 107-121.

Krueger, N. F., Reilly, M. D., \& Carsrud, A. L. (2000). Competing models of entrepreneurial intentions. Journal of Business Venturing, 15(5), 411-432.

Lucas, R, Jr. (1988). On the mechanics of economic development. Journal of Monetary Economics, 22(1), 3-42.

Mason, C. \& Brown, R. (2014). Entrepreneurial ecosystems and growth oriented entrepreneurship. Paper prepared for a workshop of the OECD LEED programme and the Dutch Ministry of Economic Affairs, The Hague, Netherlands, 7th November 2013.

McMullen, J. S., \& Dimov, D. (2013). Time and the entrepreneurial journey: The problems and promise of studying entrepreneurship as a process. Journal of Management Studies, 50(8), 1481-1512.

Mian, S. A. (2011). University's involvement in technology business incubation: What theory and practice tell us? International Journal of Entrepreneurship and Innovation Management, 13(2), 113-121.

Mian, S., Fayolle, A., \& Lamine, W. (2012). Building sustainable regional platforms for incubating science and technology businesses Evidence from US and French science and technology parks. The International Journal of Entrepreneurship and Innovation, 13(4), 235-247.

Miller, K., McAdam, M., \& McAdam, R. (2014). The changing university business model: A stakeholder perspective. $R \& D$ Management, 44(3), 265-287.

Minola, T., Domina, D., Meoli, M. (2016). Students climbing the entrepreneurial ladder: Does university internationalization pay off? Small Business Economics. doi:10.1007/ s11187-016-9758-1.

Mustar, P., \& Wright, M. (2010). Convergence or path dependency in policies to foster the creation of university spinoff firms? A comparison of France and the United Kingdom. Journal of Technology Transfer, 35(1), 42-65.

O'Shea, R., Allen, T. J., Chevalier, A., \& Roche, F. (2005). Entrepreneurial orientation, technology transfer and spinoff performance of US universities. Research Policy, 34, 994-1009.

Parker, S. C. (2011). Intrapreneurship or entrepreneurship? Journal of Business Venturing, 26(1), 19-34.
Perkmann, M., Tartari, V., McKelvey, M., Autio, E., Broström, A., D'Este, P., \& Krabel, S. (2013). Academic engagement and commercialisation: A review of the literature on university-industry relations. Research Policy, 42(2), 423-442.

Prodan, I., \& Drnovsek, M. (2010). Conceptualizing academicentrepreneurial intentions: An empirical test. Technovation, 30(5), 332-347.

Rasmussen, E., \& Borch, O. J. (2010). University capabilities in facilitating entrepreneurship: A longitudinal study of spinoff ventures at mid-range universities. Research Policy, 39(5), 602-612.

Romer, P. (1986). Increasing returns and long-run growth. The Journal of Political Economy, 94(5), 1002-1037.

Shane, S. A. (2004). Academic entrepreneurship: University spinoffs and wealth creation. Massachusetts: Edward Elgar Publishing.

Svensson, P., Klofsten, M., \& Etzkowitz, H. (2012). An entrepreneurial university strategy for renewing a declining industrial city: The Norrköping way. European Planning Studies, 20(4), 505-525.

Urbano, D., \& Guerrero, M. (2013). Entrepreneurial universities: Socio-economic impacts of academic entrepreneurship in a European region. Economic Development Quarterly, 27(1), 40-55.

Van Der Zwan, P., Verheul, I., Thurik, R., \& Grilo, I. (2013). Entrepreneurial progress: Climbing the entrepreneurial ladder in Europe and the United States. Regional Studies, 47(5), 803-825.

Wright, M., Clarysse, B., Mustar, P., \& Lockett, A. (2007). Academic entrepreneurship in Europe. Massachusetts, US: Edward Elgar Publishing.

Zahra, S., \& Wright, M. (2011). Entrepreneurship's next act. Academy of Management Perspectives, 25, 67-83.

Zhang, Q., MacKenzie, N. G., Jon-Evans, D., and Huggins, R. (2016). Leveraging knowledge as a competitive asset? The intensity, performance and structure of universities' entrepreneurial knowledge exchange activities at a regional level. Small Business Economics. doi:10.1007/s11187016-9759-0. 